\title{
Histological and endocrine characterisation of the annual luteal activity in Eurasian lynx (Lynx lynx)
}

\author{
Kim Carnaby ${ }^{1,2}$, Johanna Painer ${ }^{1}$, Arne Söderberg ${ }^{3}$, Dolores Gavier-Widèn ${ }^{3,4}$, Frank Göritz ${ }^{1}$, \\ Martin Dehnhard ${ }^{1}$ and Katarina Jewgenow ${ }^{1}$ \\ ${ }^{1}$ Leibniz Institute for Zoo and Wildlife Research (IZW), Alfred-Kowalke-Strasse 17, D-10315 Berlin, Germany, \\ ${ }^{2}$ Manchester Metropolitan University, John Dalton Building, Chester Street, Manchester M1 5GD, UK, ${ }^{3}$ Department of \\ Pathology and Wildlife Disease, National Veterinary Institute (SVA), SE-751 89 Uppsala, Sweden and ${ }^{4}$ Department of \\ Biomedical Sciences and Veterinary Public Health, Swedish University of Agricultural Sciences (SLU), 75007 \\ Uppsala, Sweden
}

Correspondence should be addressed to K Jewgenow who is now at Leibniz Institute for Zoo and Wildlife Research, PF 7000430, D-10325 Berlin, Germany; Email: jewgenow@izw-berlin.de

\begin{abstract}
Lynx presents a unique sexual cycle with persistent corpora lutea $(C L s)$ and elevated serum progesterone $\left(P_{4}\right)$ throughout parturition and lactation. In other mammals, CLs normally disintegrate after parturition, therefore the aim of our study was to characterise the annual life cycle of lynx CLs. Ovaries from Eurasian lynxes were obtained from the National Veterinary Institute in Sweden, where tissues from killed lynx were stored at $-20^{\circ} \mathrm{C}$. Ovaries from 66 animals were weighed; each corpus luteum was segmented for histology and hormone analysis. Ovary and CLs weights were constant throughout the year, peaking during pregnancy. In non-pregnant lynxes, the seasonal level of intraluteal steroids was steady for $P_{4}(3.2 \pm 1.9$ s.D. $\mu g / g, n=53)$ and total oestrogens (18.3 \pm 15.5 s.D. $\left.n g / g, n=53\right)$. Within histology slides, structurally intact luteal cells were found throughout the year with the highest incidence in March/April; evidence of luteal regression was predominantly found in post-breeding season. Ovaries from pregnant animals contained two types of CLs. Group A was bigger in size with large luteal cells $\left(P_{4}, 72.3 \pm 65.4\right.$ s.D. $\mu \mathrm{g} / \mathrm{g}$; oestrogen, $454.0 \pm 52.4$ s.D. $\left.\mathrm{ng} / \mathrm{g}\right)$. In contrast, group B were smaller, with greater luteal regression and lower steroid concentrations $\left(P_{4}, 8.3 \pm 2.9\right.$ s.D. $\mu$ g/g; oestrogen, $31.5 \pm 20.4$ s.D. ng/g). Our results suggest that structural luteolysis proceeds throughout the year and into next breeding cycle, resulting in two CLs types on the same ovary.

Reproduction (2012) 144 477-484
\end{abstract}

\section{Introduction}

The Eurasian lynx (Lynx lynx) is one of four species within the genus Lynx; the other three are the Canadian lynx (Lynx canadiensis), the bobcat (Lynx rufus) and the critically endangered Iberian lynx (Lynx pardinus; Dehnhard et al. 2010). The lynx genus typically consists of strictly seasonal breeders; the exception being the bobcat, which is a non-seasonal polyoestrous breeder (Parker \& Smith 1983, Kvam 1991, Hayssen et al. 1993).

The distribution of Eurasian lynx extends throughout Scandinavia, Russia and across China, with sparse populations in the rest of Europe and Eastern Asia (Breitenmoser et al. 2007). The global population is unclear, but the European range is estimated to contain 7000-8000 (Henriksen et al. 2005, Breitenmoser et al. 2008) animals. In sharp contrast, the Iberian lynx's current population numbers at $\sim 200$ individuals in the wild, confined to two regions of Spain (Fernandez et al. 2006, Palomares et al. 2011); the Portuguese population is possibly extinct (Von Arx \& Breitenmoser-Wüsten 2008).
The Iberian lynx suffered major population declines, mostly due to habitat loss and crippling disease within the principal prey (wild rabbit (Orytolagus cuniculus)) population (Von Arx \& Breitenmoser-Wüsten 2008). In 2003 the Iberian Lynx Ex Situ Conservation Programme was formed (Calzada et al. 2009) and at the 'El Acebuche' breeding centre in Doñana National Park, Spain, the first litter was born in 2005 (Vargas et al. 2009). Since then the population has increased within five breeding centres (four in Spain; one in Portugal) to include 96 animals (49 male: 47 female) of which 32 are founding animals and 64 were born within the programme (http://www.lynxexsitu.es). At the beginning of the programme, it was claimed that 60 individuals born in captivity would safeguard $85 \%$ of Iberian lynx genetic variability (Leus \& Lacy 2009). With that goal attained, reintroductions are now a focal point for the conservation programme.

Knowledge on reproductive biology and reliable methods for reproductive monitoring are essential for the improvement of captive breeding. The reproductive 
cycle of the Iberian and Eurasian lynx, however, was described as atypical for a cat species, whereby the corpora lutea (CLs) remain persistent and functional after parturition, lactation and into the next breeding season (Göritz et al. 2009). The corpus luteum (CL) is a temporary hormonal gland that keeps the uterine conditions optimal for pregnancy by the production of progesterone ( $\mathrm{P}_{4}$; Davis \& Rueda 2002). CL formation, maintenance and regression in many species are supported by several key hormones: luteinising hormone $(\mathrm{LH})$, prolactin, $\mathrm{P}_{4}$, oestrogens and prostaglandin $\mathrm{F}_{2 \alpha}$ (Stocco et al. 2007). The process of CL formation based on cellular restructuring of the post-ovulation follicle, triggered by a surge in $\mathrm{LH}$, is called luteinisation (Stocco et al. 2007). After ovulation, the CL helps to maintain pregnancy and then regresses during the peripartal period in almost all mammals (Stocco et al. 2007).

Within the Iberian lynx captive breeding programme, female lynx often breed unsuccessfully and the persistent CLs might prevent another cycle (Göritz et al. 2009). Thus, the reproductive potential is lost for a whole year. In the case of genetically valuable females, a hormoneinduced luteolysis followed by oestrus induction would offer a second opportunity within the current season for either natural mating or artificial insemination. However very little is known about the time course of luteal function in lynx: what differences lie between pregnant and pseudo-pregnant CLs, when CLs regress functionally and structurally and what may the triggers be?

The overall aim of this study was to investigate the annual life cycle of CLs in Eurasian lynx. This builds upon previous studies (Göritz et al. 2009) in an attempt to confirm that the origin of elevated circulating steroid hormones outside the breeding season was from the $\mathrm{CLs}$, and to find evidence of luteolysis before seasonal breeding. For this purpose ovaries from hunted or roadkilled Eurasian lynx collected throughout the year were used; this tissue availability coupled with its classification as 'Least Concern' in the IUCN Red List of Threatened Species makes the species a parallel model for research on lynx reproductive biology (Breitenmoser et al. 2008). We aimed to monitor histomorphological changes and to characterise steroidogenic function of CLs based on the analyses of the luteal key hormones: $\mathrm{P}_{4}$ and total oestrogens.

\section{Results}

\section{Seasonal weight of $C L$ and ovaries}

When evaluating non-pregnant females, both the CLs and ovarian mass did not vary significantly throughout the year (Tables 1 and 2). In pregnant females, however, ovarian mass was significantly increased in April (Table 1), while CL mass means showed a definite increase compared with non-pregnant females, although the difference was not statistically significant due to small sample size. The CLs obtained from pregnant animals were separated into two distinct categories according to size and appearance. The larger and paler CLs were designated as group A $(n=4)$, and the smaller, dark red CLs sometimes found within the same ovary were allocated into group B $(n=12)$. CLs from group A were heavier $(0.82 \pm 0.13 \mathrm{~g}$, mean \pm s.D. $)$ when compared with those of group B $(0.11 \pm 0.06 \mathrm{~g}$, mean \pm s.D.) and those from non-pregnant females $(0.13 \pm 0.08 \mathrm{~g})$. Total CLs mass was also greater in pregnant animals compared with non-pregnant animals $(2.29 \pm 0.17 \mathrm{~g}, n=2$ and $0.73 \pm 0.38 \mathrm{~g}, n=40$ respectively). The increase in CLs weight was also reflected in heavier ovaries in pregnant animals (Table 1). The heaviest ovary was found in a pregnant animal (3.29 g) and the lightest ovary was found in a non-pregnant female in August $(0.11 \mathrm{~g})$.

The number of CLs per ovary was also recorded and the highest number per ovary was eight, and per animal was 14 . The mean number of CLs per month was noted, the highest numbers were found in pregnant animals and then during January to March; the annual average was 5.9 per animal (Table 2).

\section{Histology of $C L$}

There was a certain level of decay present in many of the slides; thus a comprehensive comparative histological analysis was only possible in 26 of 53 animals. Nonetheless, many histology samples ( $n=14$, Fig. 1) showed structurally intact luteal cells throughout the year with the highest incidence in March/April (five out of seven animals, Fig. 2). Before breeding season (January-February), four out of ten cases showed evidence of luteal regression, whereas after breeding season, more than two thirds of samples demonstrated

Table 1 Annual weight variation of ovaries obtained from hunted or road-killed Eurasian lynxes in Sweden. In April, four animals were recognized as pregnant and listed separately.

\begin{tabular}{|c|c|c|c|c|c|c|c|c|c|c|}
\hline & Total & January & February & March & April & $\begin{array}{l}\text { April } \\
\text { Pregnant }\end{array}$ & $\begin{array}{l}\text { May- } \\
\text { September }\end{array}$ & October & November & December \\
\hline$n$ animal & 66 & 6 & 7 & 13 & 4 & 4 & 12 & 7 & 7 & 6 \\
\hline$n$ ovaries & 132 & 12 & 14 & 26 & 8 & 8 & 24 & 14 & 14 & 12 \\
\hline $\begin{array}{l}\text { Ovary } \\
\text { weight } \\
\text { (s.D.) }\end{array}$ & & $\begin{array}{l}0.74 \mathrm{~g} \\
( \pm 0.41 \mathrm{~g})\end{array}$ & $\begin{array}{l}0.94 \mathrm{~g} \\
( \pm 0.38 \mathrm{~g})\end{array}$ & $\begin{array}{l}1.17 \mathrm{~g} \\
( \pm 0.39 \mathrm{~g})\end{array}$ & $\begin{array}{l}0.91 \mathrm{~g} \\
( \pm 0.68 \mathrm{~g})\end{array}$ & $\begin{array}{l}1.77 \mathrm{~g}^{\mathrm{a}} \\
( \pm 0.99 \mathrm{~g})\end{array}$ & $\begin{array}{l}0.70 \mathrm{~g} \\
( \pm 0.45 \mathrm{~g})\end{array}$ & $\begin{array}{l}0.87 \mathrm{~g} \\
( \pm 0.37 \mathrm{~g})\end{array}$ & $\begin{array}{l}1.07 \mathrm{~g} \\
( \pm 0.68 \mathrm{~g})\end{array}$ & $\begin{array}{l}0.77 \mathrm{~g} \\
( \pm 0.49 \mathrm{~g})\end{array}$ \\
\hline
\end{tabular}

${ }^{\text {a }}$ The ovarian weight of pregnant animals was significantly higher compared with all other periods (Kruskal-Wallis test, $\chi^{2}=15.83, \mathrm{df}=8, P=0.04$ ). 
Table 2 Annual weight variation of corpus luteum (CL) obtained from hunted or road-killed Eurasian lynxes in Sweden. Each CL was treated separately. Because of autolytic decay not all ovaries were suitable for CL dissection.

\begin{tabular}{|c|c|c|c|c|c|c|c|c|c|c|}
\hline & Total & January & February & March & April & $\begin{array}{l}\text { April } \\
\text { Pregnant }\end{array}$ & $\begin{array}{l}\text { May- } \\
\text { September }\end{array}$ & October & November & December \\
\hline$n$ animals & 53 & 4 & 8 & 8 & 3 & 2 & 7 & 7 & 8 & 6 \\
\hline$n \mathrm{CL}$ & 314 & 29 & 48 & 55 & 16 & 16 & 35 & 38 & 44 & 33 \\
\hline $\begin{array}{l}\text { CL per } \\
\text { animal }\end{array}$ & 5.9 & 7.25 & 6 & 6.8 & 5.3 & 8 & 5 & 5.4 & 5.5 & 5.5 \\
\hline $\begin{array}{l}\mathrm{CL} \text { weight } \\
\text { (S.D.) }\end{array}$ & & $\begin{array}{l}0.11 \mathrm{~g} \\
( \pm 0.06 \mathrm{~g})\end{array}$ & $\begin{array}{l}0.09 \mathrm{~g} \\
( \pm 0.06 \mathrm{~g})\end{array}$ & $\begin{array}{l}0.12 \mathrm{~g} \\
( \pm 0.08 \mathrm{~g})\end{array}$ & $\begin{array}{l}0.19 \mathrm{~g} \\
( \pm 0.19 \mathrm{~g})\end{array}$ & $\begin{array}{l}0.29 \mathrm{~g} \\
( \pm 0.33 \mathrm{~g})\end{array}$ & $\begin{array}{l}0.14 \mathrm{~g} \\
( \pm 0.07 \mathrm{~g})\end{array}$ & $\begin{array}{l}0.10 \mathrm{~g} \\
( \pm 0.06 \mathrm{~g})\end{array}$ & $\begin{array}{l}0.13 \mathrm{~g} \\
( \pm 0.07 \mathrm{~g})\end{array}$ & $\begin{array}{l}0.10 \mathrm{~g} \\
( \pm 0.07 \mathrm{~g})\end{array}$ \\
\hline
\end{tabular}

luteal destruction (six out of nine animals). Evidence of luteal regression was described as decreased size of luteal cells and replacement by non-granulosa luteal cells (macrophages, connective tissue and theca luteal cells), as described by Dawson (1941).

In Fig. 2 (defined cell structure only) images from February and March were considered typical examples of structurally intact luteal cells. The samples from January and December presented structurally intact luteal cells with an increased proportion of connective tissues. Smaller sized luteal cells and increased volume of connective tissue were clearly visible in the presented samples from April, September, October and November.

Although the CLs obtained from pregnant lynxes were rather decayed, both pregnant $\mathrm{CL}$ types could be differentiated according to structural parameters. The CLs of pregnant group A from April were composed of large luteal cells (Fig. 2). In contrast, the pregnant group $B$, as well as the non-pregnant April CLs samples, was characterised by an increased proportion of connective tissue and smaller luteal cells; an indicator for structural disorganisation.

\section{Intraluteal steroid concentrations}

The $\mathrm{P}_{4}$ concentrations (Fig. 3) in CLs of non-pregnant animals remained stable throughout the year, independent of breeding $(4.0 \pm 1.8 \mu \mathrm{g} / \mathrm{g}$ February-April, $n=19)$ or non-breeding season $(2.6 \pm 1.6 \mu \mathrm{g} / \mathrm{g}$ May-January, $n=32$ ), but increased considerably in pregnant animals $(22.3 \pm 8.7 \mu \mathrm{g} / \mathrm{g}$ April, $n=2$, Fig. 5A). The lowest concentrations of $\mathrm{P}_{4}$ in non-pregnant animals were found between May and September $(1.7 \pm 0.7 \mu \mathrm{g} / \mathrm{g}$, $n=7)$, whereas the highest concentrations were found in March (5.2 $\pm 2.6 \mu \mathrm{g} / \mathrm{g}, n=8$, Fig. 3).

Oestrogen concentrations in non-pregnant females (Fig. 4) also showed little annual fluctuation, although the mean values were higher in February to April (39.3 $\pm 40.9 \mathrm{ng} / \mathrm{g}, n=19)$ and at lower average during MayJanuary $(15.0 \pm 12.8 \mathrm{ng} / \mathrm{g}, n=32)$. During pregnancy, however, the intraluteal oestrogen concentrations increased considerably to $181.0 \pm 103.5 \mathrm{ng} / \mathrm{g} \quad(n=2$; Fig. 5B). The lowest concentrations of oestrogen in non-pregnant animals were found in December (10.7 $\pm 4.8 \mathrm{ng} / \mathrm{g}, n=6)$ and the highest in April (65.2 $\pm 61.8 \mathrm{ng} / \mathrm{g}, n=3)$. From March to October very high variation of the intraluteal oestrogen was found, with few individual CLs in excess of $100 \mathrm{ng} / \mathrm{g}$ (Fig. 4).

There were two pregnant animals in our hormone study, confirmed by the presence of two foetuses each. The concentrations of both hormones within the CLs were considerably higher in the pregnant animals compared with non-pregnant (Fig. 5A and B). Group A contained CLs that were bigger in size and characterised by pale colour. The steroid content in group $A$ was higher with $72.3 \pm 65.4 \mu \mathrm{g} / \mathrm{g}$ for $\mathrm{P}_{4}$ and $454.0 \pm 52.4 \mathrm{ng} / \mathrm{g}$ for oestrogen. In contrast CLs of group $B$, which were markedly smaller in size and dark red in colouration, had lower concentrations of intraluteal steroids $\left(\mathrm{P}_{4}, 8.3\right.$ $\pm 2.9 \mu \mathrm{g} / \mathrm{g}$; oestrogen, $31.5 \pm 20.4 \mathrm{ng} / \mathrm{g}$ ).

\section{Hormone values outside normal variation}

Within the sample set, some CLs expressed unusually high hormone values (Figs 3 and 4). A threshold of two S.D.s from the mean of non-pregnant animals in both $\mathrm{P}_{4}$ $(9.3 \mu \mathrm{g} / \mathrm{g})$ and oestrogen $(66.3 \mathrm{ng} / \mathrm{g})$ was used to classify animals as having unusually high readings. As expected, almost all CLs of the two pregnant animals fell into this

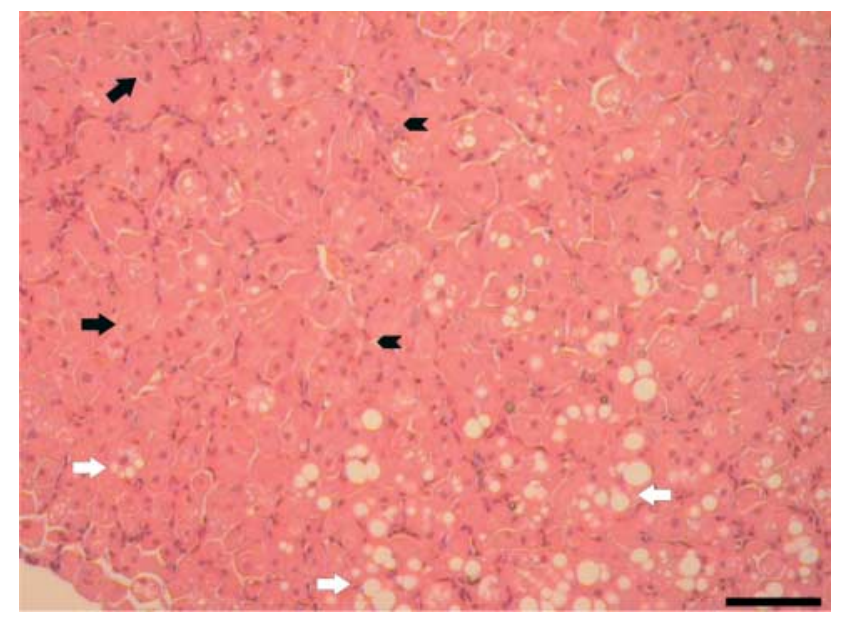

Figure 1 Histological picture of luteal tissue from a corpus luteum obtained from a hunted Eurasian lynx in February. Different luteal cell types are marked as followed: black arrow, structurally intact luteal granulosa cells; white arrows, luteal cells with foamy cytoplasma indicating lipid accumulation; black arrow heads, non-luteal stroma cells. Scale bar $=40 \mu \mathrm{m}$. 


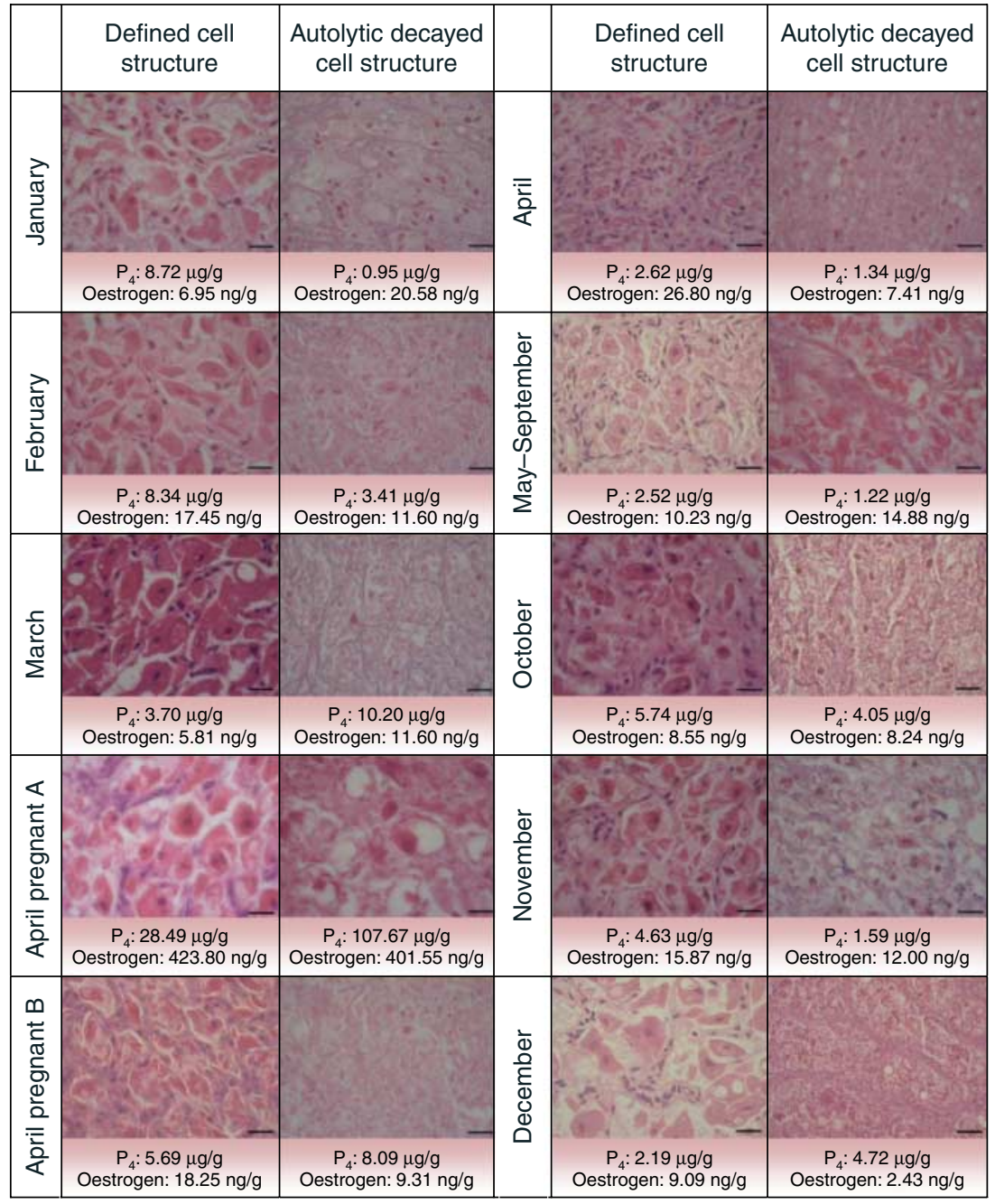

Figure 2 Histological appearance of corpora lutea obtained from hunted or road-killed Eurasian lynx in Sweden. Transportation and freezing of whole lynx carcasses resulted in different degree of decay. For each month and two pregnant CL groups (groups A and B) a sample with good and poor histology are depicted together with the determined intraluteal steroid content. Scale bar $=$ $20 \mu \mathrm{m} . \mathrm{P}_{4}$, intraluteal progesterone. region as did nine other animals. Six non-pregnant samples contained extraordinarily high oestrogen; they were found between January and July and once in October. Elevated $\mathrm{P}_{4}$ was found in only three nonpregnant animals; these samples were from March, October and November.

\section{Discussion}

Many lynx reproductive studies in history have looked at factors such as placental scars and CL numbers (Duke 1949, Kvam 1990), but this is the first study that has incorporated CL morphology and steroid production. As expected, we found a significant increase in ovarian mass and $\mathrm{P}_{4}$ and oestrogen production in CLs of pregnant animals, with a clear morphological and hormonal distinction between two types of CLs in one ovary. In non-pregnant animals, no significant changes were found throughout the year indicating permanent but low-level luteal functions. Our data suggest normal luteal activity during pregnancy and also support our earlier hypothesis about the persistence of CLs during the entire year (Göritz et al. 2009) and into the next breeding season.

The breeding season of lynxes in Scandinavia lasts from February till early April, with mating activity peaking in March (Kvam 1991). Accordingly, highest ovarian weights were found in pregnant animals and in March. The largest CLs, however, were exclusively found in pregnant animals, although clearly two kinds of CLs were distinguished (groups $\mathrm{A}$ and $\mathrm{B}$ ) suggesting that previous years CLs regress only after the formation of the current season's functional CLs. In the domestic cat, CLs reach their maximum size $\sim 2$ weeks after ovulation (Dawson 1941) independently of pregnancy or pseudo-pregnancy. The implantation of domestic cat embryos is observed at 12-14 days after ovulation (Denker et al. 1978, Leiser 1979), thus coinciding with CL formation.

Kvam (1991) also analysed ovaries of hunted lynxes. He already described the presence of luteal bodies throughout the entire year and differences in colour and consistency of luteal bodies from previous cycles (' 1 year later'). In some lynxes the presence of luteal bodies from 


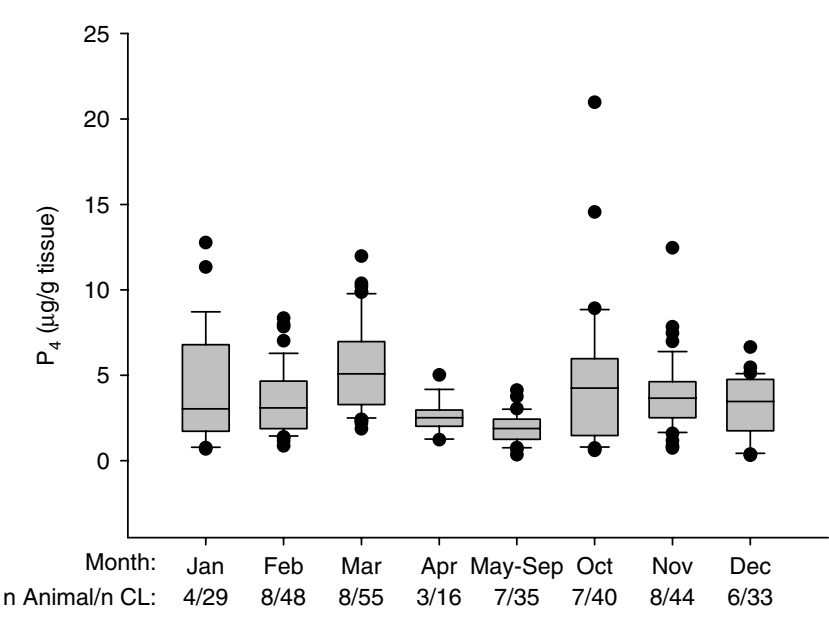

Figure 3 Box-plots of the annual intraluteal progesterone $\left(\mathrm{P}_{4}\right)$ values determined in corpora lutea of hunted or road-killed Eurasian lynx. All animals were diagnosed non-pregnant by gross-morphological inspections of the uterus. The progesterone level did not differ between the months $\left(\chi^{2}=13.35, \mathrm{df}=7, P=0.06\right)$.

three cycles (3 years) was suggested; with a mean of six CLs per animal, our data corroborates this theory. In addition, the number of CLs in the ovaries was found to be much higher than the mean litter size $(\sim 2)$ described for the Eurasian lynx (Kvam 1991, Henriksen et al. 2005). Other possible reasons for this disparity might be a high embryonal loss or remnant CLs from previous ovulations of same breeding season. In our study, the number of foetuses in the two pregnant animals was exactly matched by the number of active (group A) CLs, suggesting that adjacent CLs may originate from a previous year's ovulations.

Although the mean number of CLs per animal did not reveal a clear pattern, higher numbers of CLs were found just before and during the breeding season (January-April, $>7$ ) in comparison to the rest of the year $($ mean $=5)$, when young females $(<3$ years old $)$ were removed from the comparison. We suggest that this reflects a permanent turnover of CLs, with a delay of structural luteolysis of at least 1 year following ovulation.

To further characterise the function of CLs in lynx, luteal $\mathrm{P}_{4}$ and oestrogens were determined in order to clarify the difference between the CLs that were still functional, and those which had undergone luteolysis. Both steroid hormones, $\mathrm{P}_{4}$ and oestrogens, were still detectable in decayed samples; conversely, low steroid values were obtained from morphologically welldefined samples. Thus, the degenerative state of luteal cells seemed to have no relationship with the amount of hormones detected (Fig. 2). Data from our previous studies on serum $\mathrm{P}_{4}$ and sono-morphology of lynx CLs during the annual cycle point towards permanent luteofunction throughout the year (Göritz et al. 2009). The presence of CLs from previous cycles has been verified in the mouse, rat, baboon (Davis \& Rueda 2002) and even domestic cats during lactation (Dawson 1946). In the domestic cat, however, serum $\mathrm{P}_{4}$ decreases to the baseline level after parturition, although the structure of CLs might be conserved by the luteotrophic action of prolactin (Banks et al. 1983). It is impossible to differentiate between functionally active and inactive luteal cells by light microscope alone, as both types can be morphologically indistinguishable. However, in rodents, during functional luteolysis, the $\mathrm{CL}$ is still steroidogenically active, but instead of $\mathrm{P}_{4}$ it continues to produce an inactive $\mathrm{P}_{4}$ metabolite (Stocco et al. 2007). As our $\mathrm{P}_{4}$ assay was validated for cross reactivity to the determined inactive metabolite (4-pregnen-20 $\alpha$-ol-3one, $<0.01 \%$ ) and several $\mathrm{P}_{4}$ metabolites, it is unlikely that progestins other than $\mathrm{P}_{4}$ were detected in our assay. Furthermore, in contrast to the domestic cat, and many other species (Stocco et al. 2007) with post partum persistence of $\mathrm{CLs}$, we were also able to determine elevated serum $\mathrm{P}_{4}$ concentrations above baseline (juvenile and aged females $<0.1 \mathrm{ng} / \mathrm{ml}$ ) during pseudo-pregnancy and outside breeding season ( $5 \mathrm{ng} / \mathrm{ml}$, Göritz et al. 2009).

Swanson et al. (1995) analysed $\mathrm{P}_{4}$ content in the domestic cat CLs in relation to the serum levels and revealed a strong correlation among serum $\mathrm{P}_{4}$, luteal mass and luteal $\mathrm{P}_{4}$. After $\mathrm{CL}$ formation $(64 \mathrm{~h}$ post copulation), the $\mathrm{P}_{4}$ level corresponded to the level which we determined within the pregnant lynx CLs, whereas 20 days after ovulation the $\mathrm{P}_{4}$ amount in domestic cats, reported from Swanson et al. (1995), exceeded our $\mathrm{P}_{4}$ content by a factor of ten $(160-200 \mu \mathrm{g} / \mathrm{g})$. Irrespective of this discrepancy, our $\mathrm{P}_{4}$ concentrations in pregnant CLs were significantly elevated in comparison to any other period of the year, including nonpregnant CLs within the breeding period (March-April). The relationship fits with serum samples for steroid

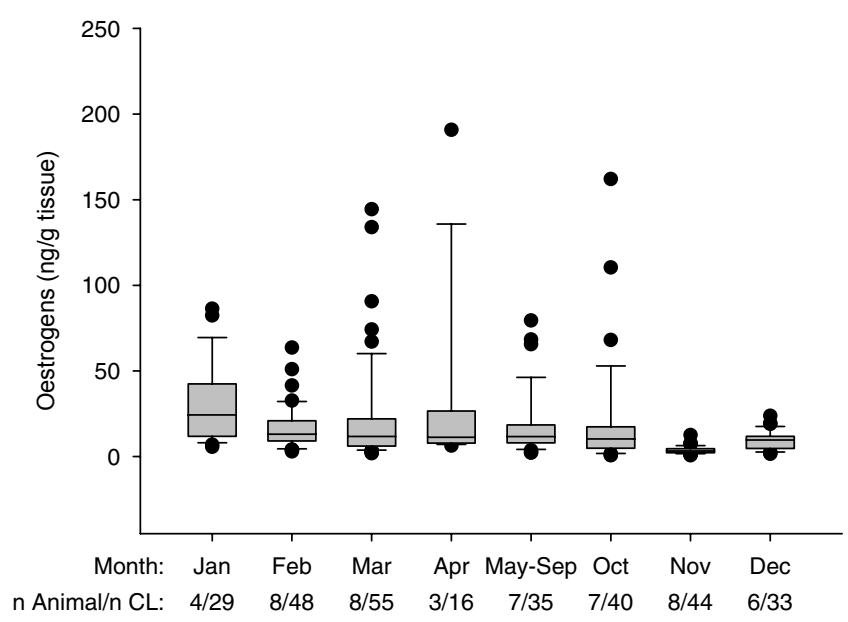

Figure 4 Box-plots of the annual intraluteal oestrogens values determined in corpora lutea of hunted or road-killed Eurasian lynx. All animals were diagnosed non-pregnant by gross-morphological inspections of the uterus. The total oestrogens level did not differ between the months $\left(\chi^{2}=12.30, \mathrm{df}=8, P=0.41\right)$. 


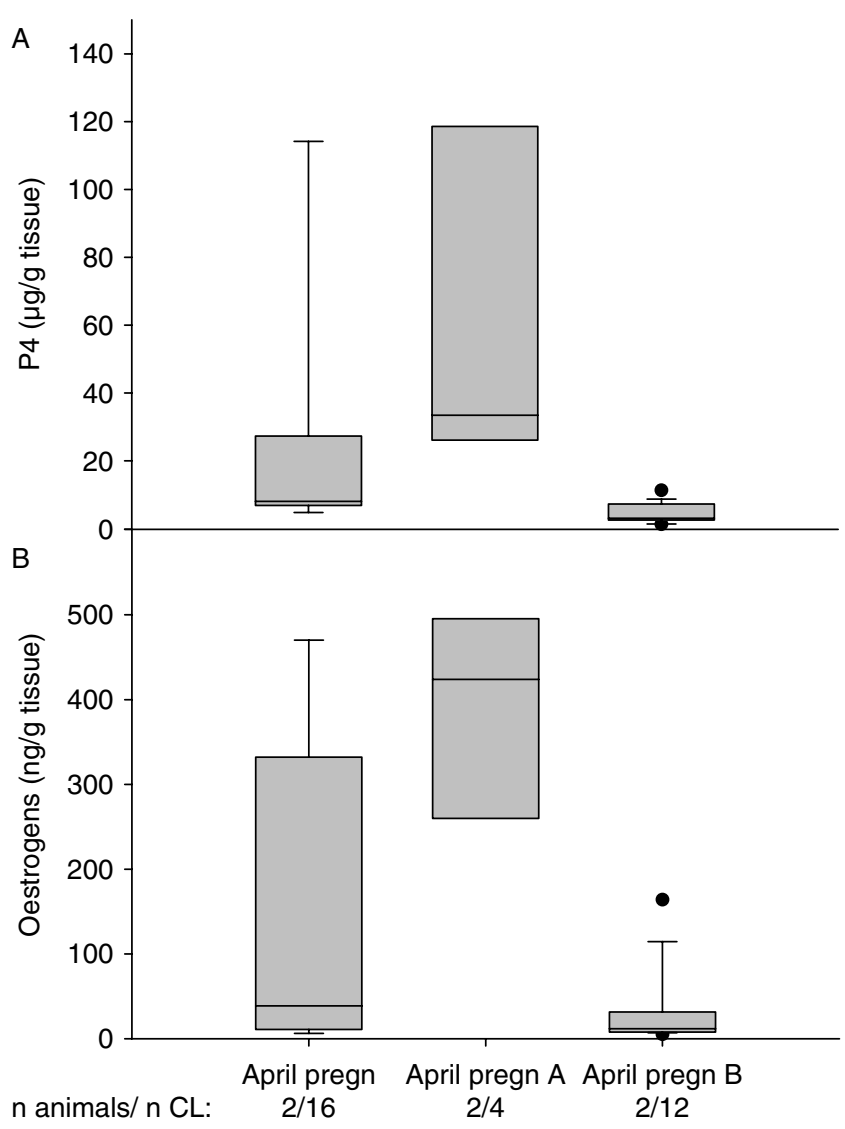

Figure 5 Box-plots of progesterone (A) and oestrogens (B) concentration determined in CLs from two pregnant lynxes hunted in April. The pregnancies were confirmed by the presence of two foetuses in each animal. The two qualities of CLs on the ovaries were divided into group A, big size and pale colour and group B, small and dark red colour - CLs. The morphological-based categorisation was confirmed by higher $\mathrm{P}_{4}$ and oestrogen levels within the luteal tissue.

determination we analysed during annual reproductive assessments (Göritz et al. 2009). Here blood serum $P_{4}$ was found to be ten times higher during pregnancy, compared with samples collected during pseudopregnancy, lactation, and outside the breeding period (Göritz et al. 2009).

Interestingly, the highest oestrogen concentrations were found in CLs of pregnant lynxes, signalling an involvement of this steroid in the maintenance of pregnancy. Non-invasive monitoring of steroids in urine and faecal samples of Eurasian and Iberian lynxes corroborates the special role of oestrogens during pregnancy in lynxes; showing elevated profiles of urinary and faecal oestrogen metabolites in pregnant animals, which were correlated to progestin metabolites (Dehnhard et al. 2008, Jewgenow et al. 2009). In contrast to $\mathrm{P}_{4}$, elevated oestrogens were not reflected in serum oestradiol $\left(E_{2}\right)$ levels (Göritz et al. 2009). Limited CLs from non-pregnant lynxes contained extraordinarily high oestrogens. With one exception, these animals were within the breeding season.
Therefore, we suggest that oestrogens might precede the $\mathrm{P}_{4}$ elevation after ovulation. A group of three nonpregnant lynxes (from March, October and November) were characterised by extraordinary high $\mathrm{P}_{4}$; here we suggest either an ongoing pseudo-pregnancy or elevated $\mathrm{P}_{4}$ levels caused by lactation (action of luteotrophic hormone, prolactin). Further investigations with a larger sample size are needed to support this hypothesis.

The mechanisms behind functional and structural luteal regression in the lynx are not yet known. In many species, the prostaglandin $\mathrm{PGF}_{2 \alpha}$ is involved in functional CL regression (Moutos et al. 1995, Davis \& Rueda 2002, Stocco et al. 2007, Finkenwirth et al. 2010, Siemieniuch et al. 2010) and it seems to also play a major role in lynxes. We could recently show that PGFM, the metabolite of $\mathrm{PGF}_{2 \alpha}$, significantly increases at the beginning of last pregnancy trimester (Finkenwirth et al. 2010); a period in domestic cats when pregnancy is not exclusively dependant upon CLs (Tsutsui et al. 2009) and placental tissue might contribute towards $\mathrm{P}_{4}$ production.

Also in the domestic cat, signs of structural luteolysis were described after day 50 of pregnancy, when CLs decrease in size and the luteal cells become highly vacuolated (Dawson 1941). The fatty infiltration of luteal tissue throughout the remainder of pregnancy and during post partum involution was regarded as an evidence of degeneration, marking the end of the period of functional activity of the CLs. The same evidence could be seen in lynx CLs as late as December (Fig. 2) or just before breeding season. The final stages of luteal regression were characterised by very small luteal cells and a prevalence of connective tissue as shown for CLs in April (non-pregnant or group B). This final structural luteal regression begins with programmed cell death (apoptosis) and involution of the $\mathrm{CL}$, and culminates in an ovarian scar called corpus albicans (Davis \& Rueda 2002, Luz et al. 2006, Stocco et al. 2007).

Continued post-mortem hormone analysis of CLs may provide valuable information on reproductive cyclicity in lynx. Eurasian lynxes are hunted at the onset of breeding season. In future studies, we will focus on fresh material from newly hunted lynxes to combine morphological and endocrine studies on CLs with particular emphasis on molecular determination of factors involved in the synthesis of steroids and prostaglandins, hormone reception and apoptosis.

\section{Materials and Methods}

\section{The animals and tissue sample collection}

The Eurasian lynx used in this study were from Sweden, whose population numbers are 1300-1600 individuals (Andren et al. 2002, Liberg \& Andren 2006); an annually reviewed legal hunting quota is permitted in order to maintain population levels which preserve the status quo between livestock holders 
affected by lynx predation, hunters and government agencies (management plan for large carnivores, proposition 2008/ 09:210, http://www.ud.se/sb/d/108/a/127782, accessed 15/01/ 12). All lynx kills must be delivered to the National Veterinary Institute (SVA), Uppsala, Sweden, including legally hunted and $\mathrm{road} /$ train fatalities. At the institute the tissue was frozen soon after the animal was necropsied; samples included in this study were harvested between 2003 and 2010 and kept in frozen storage $\left(-20{ }^{\circ} \mathrm{C}\right)$ in a tissue-bank facility. From a total of 66 animals used in this study, all were suitable for total ovary weight analysis, 53 suitable for hormone analysis and 42 for total CLs weight data.

Ovaries and uteri were defrosted, weighed, and dissected. Each CL was weighed and cut into segments; one smaller part for histology and the remainder for determination of intraluteal steroid hormone content by enzyme immunoassay analysis. The samples were grouped per month except during MaySeptember, when sample numbers were too low and had to be pooled. Four animals were found to be pregnant based on the presence of foetuses within the uterus.

\section{Histology of CL}

A section of $C L$ tissue was fixed in Bouin solution, embedded in paraffin, cut into $2-3 \mu \mathrm{m}$ slices and stained with haematoxylineosin (Fig. 1). Slides were examined using a light microscope with a digital camera (Olympus Soft Imaging Solutions, Münster, Germany), mounted at magnifications of $\times 20$ and $\times 40$ and processed using the cell $\mathrm{R}$ Software (Olympus) to ascertain the degree of autolysis, intactness of luteal cells and presence of lipid vacuoles as well as signs of structural degradation (replacement by non-luteal cells, as described by Dawson (1941)).

\section{Intraluteal steroid hormone determination}

Aliquots of $\mathrm{CL}$ tissue of $0.01-0.61 \mathrm{~g}$ were placed into $2 \mathrm{ml}$ centrifuge tubes containing 28 and $14 \mathrm{~mm}$ ceramic balls (Precellys, Bertin Technologies, Montigny-le-Bretonneux, France), to which a sample weight-specific volume of 0.09-1.12 ml PBS was added; the samples were placed in a 'Precellys 24' homogenizer (Precellys) and shaken at $7000 \mathrm{~g}$ for $2 \times 15 \mathrm{~s}$. An aliquot $(50 \mu \mathrm{l})$ of the homogenate was extracted twice with $2 \mathrm{ml}$ of tert-butyl methyl ether/petroleum ether $(30 / 70, v / v)$ for $30 \mathrm{~min}$. After freezing at $-75^{\circ} \mathrm{C}$, the organic phase was decanted, dried and resolved with $0.25 \mathrm{ml}$ of $40 \%$ methanol and stored at $-20{ }^{\circ} \mathrm{C}$ until needed.

Duplicates of the extracts ( 20 and $10 \mu \mathrm{l}$ respectively) were tested for both $\mathrm{P}_{4}$ and oestrogens using in-house 96 well microtitre plate enzyme immunoassays previously validated for the Eurasian lynx (Dehnhard et al. 2008).

$\mathrm{P}_{4}$ analyses were carried out as described earlier (Dehnhard et al. 2010) using a commercial $P_{4}$ antibody (Sigma P1922, raised in rats) and 4-pregnen-3,20-dione-3-CMO-peroxidase label. The cross reactivities to progestins were as follows: 4-pregnen3,20-dione $\left(\mathrm{P}_{4}\right), \quad 100 \%$; 5 $\alpha$-pregnan-3,20-dione, 31\%; $5 \alpha$-pregnan-3 $\beta$-ol-20-one, $18 \%$; 5 -pregnen-3 $\beta$-ol-20-one, $12 \%$; 4-pregnen-3 $\alpha$ ol-20-one, $4.2 \% ;<0.1 \%$ for $5 \beta$-pregnan- $3 \alpha$, $20 \alpha$ diol, 4-pregnen-20 $\alpha$-ol-3-one, $5 \beta$-pregnan-3 $\alpha$-ol-20-one,
$5 \alpha$-pregnan-20 $\alpha$-ol-3-one, $5 \alpha$-pregnan-3 $\alpha, 20 \alpha$-diol, $5 \alpha$-pregnan-3 $\beta, 20 \alpha$-diol, testosterone, $E_{2}$, and cortisol. Intra- and inter-assay coefficients of variation $(\mathrm{CVs})$ for two biological samples with low and high concentrations were 1.8 and $8.6 \%$ $(n=18)$ and 2.1 and $8.5 \%(n=20)$ respectively.

Total oestrogen analyses were carried out using a polyclonal antibody raised in rabbits to $1,3,5(10)$-estratrien-3,17 $\beta$ diol-17-HS-BSA and 1,3,5(10)-estratrien-3,17 $\beta$-diol-17HS-peroxidase label. The cross reactivities to oestrogens were as follows: 1,3,5(10)-estratrien-3,17 $\beta$-diol $\left(17 \beta-\mathrm{E}_{2}\right), 100 \%$; 1,3,5(10)-estratrien-3,17-one (oestrone), 100\%; 1,3,5(10)estratrien-3,17 $\alpha$-diol $\left(17 \alpha-E_{2}\right), 66 \% ; 1,3,5(10)$-estratrien$3,16 \alpha, 17 \beta$-triol (oestriol), $1.5 \%$; and $<0.1 \%$ for 19 -nortestosterone, $\mathrm{P}_{4}$ and testosterone. Intra- and inter-assay $\mathrm{CVs}$ for two biological samples with low and high concentrations were 2.4 and $6.9 \%(n=12)$ and 1.3 and $4.7 \%(n=18)$ respectively.

In order to assess the influence of prolonged storage of CLs at ambient temperatures on intraluteal steroid concentration, some preliminary testing was carried out on CLs obtained from the domestic cat $(n=4)$ after ovariotomy. CLs were kept at refrigerator temperature $\left(4^{\circ} \mathrm{C}\right)$ and room temperature $\left(20{ }^{\circ} \mathrm{C}\right)$ for $0,1,2$ and 3 days before processing. All measurements followed the same protocol as described above. Steroid hormone concentrations remained constant throughout the four days storage period at both refrigerator and room temperature.

\section{Statistical analysis}

The software package 'R version 2.14.1.' (Vienna, Austria) was applied in all statistical analyses ( $R$ Development Core Team 2011). Data on ovarian and CLs weight were displayed using mean \pm s.D. Hormone content was expressed as microgram $\mathrm{P}_{4}$ or nanogram oestrogens per gram of wet CL tissue in box-plots presenting medians together with 10, 25, 75 and $90 \%$ percentiles. As the distribution of the data was not normal, non-parametric statistical analysis methods were used in the form of a Kruskal-Wallis analysis of variance generalized linear model. Means were used to make data independent. For analysis of total ovary and total CLs data, only data from animals that had either both ovaries $(n=66)$ or $C L$ present in both ovaries $(n=42)$ were considered.

\section{Declaration of interest}

The authors declare that there is no conflict of interest that could be perceived as prejudicing the impartiality of the research reported.

\section{Funding}

Funding was provided by the German Ministry of Education and Research (BMBF Number 033L046).

\section{Acknowledgements}

The authors like to thank Prof. Jon M Arnemo for providing the contact details to the fruitful cooperation between IZW and SVA. Marlies Rohleder, Katrin Paschmionka and Sigrid Holz are 
appreciated for their technical expertise. Statistical advice was gratefully received by Dr W Edwin Harris. The authors would like to thank the personnel at the Division of Wildlife Diseases at SVA, in particular Jessica Åsbrink, for the collection of specimens and recording of lynx data.

\section{References}

Andren $\mathrm{H}$, Linnell JDC, Liberg $\mathrm{O}$, Ahlqvist P, Andersen R, Danell A, Franzen R, Kvam T, Odden J \& Segerstrom P 2002 Estimating total lynx (Lynx lynx) population size from censuses of family groups. Wildlife Biology 8 299-306.

Banks DR, Paape SR \& Stabenfeldt GH 1983 Prolactin in the cat: I. Pseudopregnancy, pregnancy and lactation. Biology of Reproduction $\mathbf{2 8}$ 923-932. (doi:10.1095/biolreprod28.4.923)

Breitenmoser U, Breitenmoser-Würsten C, Capt S, Molinari-Jobin A, Molinari P \& Zimmermann F 2007 Conservation of the lynx (Lynx lynx) in the Swiss Jura mountains. Wildlife Biology 13 340-355. (doi:10.2981/ 0909-6396(2007)13 [340:COTLLL]2.0.CO;2)

Breitenmoser U, Mallon DP, von Arx M \& Breitenmoser-Wüsten C 2008 Lynx lynx. In IUCN 2011. IUCN Red List of Threatened Species, version 2011.2. www.iucnredlist.org. Accessed 02 December 2011.

Calzada J, Gonzalez LM, Guzman N \& Heredia B 2009 A new strategy for the conservation of the Iberian lynx. In Iberian lynx Ex Situ Conservation: an Interdisciplinary Approach, pp 22-31. Eds A Vargas, C Breitenmoser \& U Breitenmoser. Madrid: Fundacion Biodiversidad.

Davis JS \& Rueda BR 2002 The corpus luteum: an ovarian structure with maternal instincts and suicidal tendencies. Frontiers in Bioscience: a Journal and Virtual Library 7 d1949-d1978. (doi:10.2741/davis1)

Dawson AB 1941 The development and morphology of the corpus luteum of the cat. Anatomical Record 79 155-177. (doi:10.1002/ar. 1090790203)

Dawson AB 1946 The postpartum history of the corpus luteum of the cat. Anatomical Record 95 29-51. (doi:10.1002/ar.1090950105)

Dehnhard M, Naidenko S, Frank A, Braun B, Göritz F \& Jewgenow K 2008 Non-invasive monitoring of hormones: a tool to improve reproduction in captive breeding of the Eurasian lynx. Reproduction in Domestic Animals 43 (Suppl 2) 74-82. (doi:10.1111/j.1439-0531.2008.01145.x)

Dehnhard M, Fanson K, Frank A, Naidenko SV, Vargas A \& Jewgenow K 2010 Comparative metabolism of gestagens and estrogens in the four lynx species, the Eurasian (Lynx lynx), the Iberian (L. pardinus), the Canada lynx (L. canadensis) and the bobcat (L. rufus). General and Comparative Endocrinology 167 287-296. (doi:10.1016/j.ygcen.2010. 03.023)

Denker HW, Eng LA, Mootz U \& Hamner CE 1978 Studies on the early development and implantation in the cat: 1 . Cleavage and blastocyst formation. Anatomischer Anzeiger 144 457-468.

Duke KL 1949 Some notes on the histology of the ovary of the bobcat with special reference to the corpora lutea. Anatomical Record 103 111-131. (doi:10.1002/ar.1091030108)

Fernandez N, Delibes M \& Palomares F 2006 Landscape evaluation in conservation: molecular sampling and habitat modeling for the Iberian lynx. Ecological Applications: a Publication of the Ecological Society of America 16 1037-1049. (doi:10.1890/1051-0761(2006)016[1037:LEIC $\mathrm{MS}] 2.0 . \mathrm{CO} ; 2)$

Finkenwirth C, Jewgenow K, Meyer HHD, Vargas A \& Dehnhard M 2010 PGFM (13,14-dihydro-15-keto-PGF(2 $\alpha)$ ) in pregnant and pseudopregnant Iberian lynx: a new noninvasive pregnancy marker for felid species. Theriogenology 73 530-540. (doi:10.1016/j.theriogenology. 2009.10.008)

Göritz F, Dehnhard M, Hildebrandt TB, Naidenko SV, Vargas A, Martinez F, Lopez-Bao JV, Palomares F \& Jewgenow K 2009 Non cat-like ovarian cycle in the Eurasian and the Iberian lynx - ultrasonographical and endocrinological analysis. Reproduction in Domestic Animals 44 (Suppl 2) 87-91. (doi:10.1111/j.1439-0531.2009.01380.x)

Hayssen V, Van Tienhoven A \& Van Tienhoven A 1993 In Asdell's Pattern of Mammalian Reproduction: A Compendium of Species-Specific Data. Ithaca, NY, USA: Cornell University Press.
Henriksen HB, Andersen R, Hewison AJM, Gaillard JM, Bronndal M, Jonsson S, Linnell JDC \& Odden J 2005 Reproductive biology of captive female Eurasian lynx, Lynx lynx. European Journal of Wildlife Research 51 151-156. (doi:10.1007/s10344-005-0104-1)

Jewgenow K, Göritz F, Vargas A \& Dehnhard M 2009 Seasonal profiles of ovarian activity in Iberian lynx (Lynx pardinus) based on urinary hormone metabolite analyses. Reproduction in Domestic Animals 44 92-97. (doi:10.1111/j.1439-0531.2009.01383.x)

Kvam T 1990 Ovulation rates in European lynx, Lynx lynx (L), from Norway. Zeitschrift Fur Saugetierkunde 55 315-320.

Kvam T 1991 Reproduction in the European lynx, Lynx lynx. Zeitschrift Fur Saugetierkunde 56 146-158.

Leiser R 1979 Blastocyst implantation in the domestic cat. Light and electron microscopic study. Anatomia, Histologia, Embryologia 8 79-96. (doi:10.1111/j.1439-0264.1979.tb00681.x)

Leus K \& Lacy RC 2009 Genetic and demographic management of conservation breeding programmes oriented towards reintroduction. In Iberian lynx Ex Situ Conservation: an Interdisciplinary Approach, pp 74-85. Eds A Vargas, C Breitenmoser \& U Breitenmoser. Madrid: Fundacion Biodiversidad.

Liberg O \& Andren H 2006 The lynx population in Sweden 1994-2004: an evaluation of census data and methods. Wildlife Damage Centre/Grimsö Wildlife Research Station, Swedish University of Agricultural Sciences SLU: Riddarhyttan, Sweden.

Luz MR, Cesario MD, Binelli M \& Lopes MD 2006 Canine corpus luteum regression: apoptosis and caspase-3 activity. Theriogenology 66 1448-1453. (doi:10.1016/j.theriogenology.2006.02.025)

Moutos D, Schryer B, Hurn P \& Dharmarajan AM 1995 Effect of exogenous oestrogen on blood flow and quantitative histology of the corpora lutea of pseudopregnant rabbits. Journal of Reproduction and Fertility 103 357-362. (doi:10.1530/jrf.0.1030357)

Palomares F, Rodriguez A, Revilla E, Lopez-Bao JV \& Calzada J 2011 Assessment of the conservation efforts to prevent extinction of the Iberian lynx. Conservation Biology 25 4-8. (doi:10.1111/j.1523-1739. 2010.01607.x)

Parker G \& Smith G 1983 Sex- and age-specific reproductive and physical parameters of the bobcat (Lynx rufus) on Cape Breton Island, Nova Scotia. Canadian Journal of Zoology 61 1771-1782. (doi:10.1139/z83-229)

R Development Core Team 2011 R: a language and environment for statistical computing. R Foundation for Statistical Computing: Vienna, Austria.

Siemieniuch MJ, Bowolaksono A, Skarzynski DJ \& Okuda K 2010 Ovarian steroids regulate prostaglandin secretion in the feline endometrium. Animal Reproduction Science 120 142-150. (doi:10.1016/j.anireprosci. 2010.02.020)

Stocco C, Telleria C \& Gibori G 2007 The molecular control of corpus luteum formation, function, and regression. Endocrine Reviews $\mathbf{2 8}$ 117-149. (doi:10.1210/er.2006-0022)

Swanson WF, Roth TL, Brown JL \& Wildt DE 1995 Relationship of circulating steroid hormones, luteal luteinizing hormone receptor and progesterone concentration, and embryonic mortality during early embryogenesis in the domestic cat. Biology of Reproduction $\mathbf{5 3}$ 1022-1029. (doi:10.1095/biolreprod53.5.1022)

Tsutsui T, Suzuki Y, Toyonaga M, Oba H, Mizutani T \& Hori T 2009 The role of the ovary for the maintenance of pregnancy in cats. Reproduction in Domestic Animals 44 (Suppl 2) 120-124. (doi:10.1111/j.1439-0531. 2009.01452.x)

Vargas A, Sanchez I, Martinez F, Rivas A, Godoy JA, Roldan ER, Simon MA, Sierra R, Perez MJ, Sliwa A et al. 2009 Interdisciplinary methods in the Iberian lynx (Lynx pardinus) conservation breeding programme. In Iberian lynx Ex Situ Conservation: an Interdisciplinary Approach, pp 59-71. Eds A Vargas, C Breitenmoser \& U Breitenmoser. Madrid, Spain: Fundacion Biodiversidad.

Von Arx M \& Breitenmoser-Würsten C 2008 Lynx pardinus. In IUCN 2011. IUCN Red List of Threatened Species, version 2011.2. www.iucnredlist.org. Accessed 02 December 2011.

Received 4 May 2012

First decision 8 June 2012

Accepted 6 July 2012 